\title{
PRINSIP DASAR METODE PENGAJARAN BAHASA ARAB
}

\author{
Oleh: Abdullah Isa \\ abdullahis@gmail.com \\ STAI Taruna Surabaya
}

\begin{abstract}
Abstrak: Ada tiga prinsip dasar dalam pengajaran bahasa Arab, yaitu prinsip prioritas dalam proses penyajian materi ajar, prinsip koreksitas dan umpan balik, prinsip bertahap dalam penyampaian materi kepada peserta didik.

Ada beberapa langkah aplikasi yang diperlukan dalam pengajaran bahasa Arab, agar teknik penyampaian materi berhasil dan dapat terlaksana, yaitu: Memberikan contoh sebelum memberikan kaidah gramatika, memberikan contoh kalimat yang biasa dipakai sehari-hari, dan memberikan motivasi yang cukup untuk berekspresi melalui tulisan, lisan bahkan mungkin ekspresi wajah, agar meraka merasa terlibat langsung dengan proses pengajaran yang berlangsung.

Ada dua macam metode pengajaran bahasa Arab, yaitu: pertama, metode tradisional, yaitu metode pengajaran bahasa yang terfokus pada "bahasa sebagai budaya ilmu" sehingga belajar bahasa Arab berarti belajar secara mendalam tentang seluk-beluk ilmu bahasa Arab itu sendiri. Dan kedua, metode modern, yaitu metode pengajaran yang berorientasi pada tujuan bahasa sebagai alat komunikasi dalam kehidupan modern.
\end{abstract}

Kata Kunci: Pengajaran, Bahasa, Arab.

\section{A. Prinsip-prinsip Pengajaran Bahasa Arab}

Ada tiga prinsip dasar dalam pengajaran bahasa Arab, yaitu prinsip prioritas dalam proses penyajian, prinsip koreksitas dan umpan balik, prinsip bertahap.

\section{Prinsip Prioritas}

Dalam pembelajaran bahasa Arab, ada prinsip-prinsip prioritas dalam penyampaian materi pengajaran, yaitu:

a. Mengajarkan, mendengarkan, dan bercakap sebelum menulis

b. Mengajarkan kalimat sebelum mengajarkan kata.

c. Menggunakan kata-kata yang lebih akrab dengan kehidupan sehari-hari sebelum mengajarkan bahasa sesuai dengan dialek bahasa Arab. 
1) Mendengar dan berbicara terlebih dahulu daripada menulis. Prinsip ini berangkat dari asumsi bahwa pengajaran bahasa yang baik adalah pengajaran yang sesuai dengan perkembangan bahasa yang alami pada manusia, yaitu setiap anak akan mengawali perkembangan bahasanya dari mendengar dan memperhatikan kemudian menirukan. Hal itu menunjukkan bahwa kemampuan mendengar/menyimak harus lebih dulu dibina, kemudian kemampuan menirukan ucapan, lalu aspek lainnya seperti membaca dan menulis. Ada beberapa teknik melatih pendengaran/telinga, yaitu:

a) Guru bahasa Arab hendaknya mengucapkan kata-kata yang beragam, baik dalam bentuk huruf maupun dalam kata. Sementara peserta didik menirukannya secara kolektif.

b) Guru bahasa Arab kemudian melanjutkan materinya tentang bunyi huruf yang hampir sama sifatnya.

c) Selanjutnya materi diteruskan dengan tata bunyi yang tidak terdapat di dalam bahasa ibu (hal ini bahasa indonesia) peserta didik. Adapun dalam pengajaran pengucapan dan peniruan dapat menempuh langkah-langkah berikut.

i. Peserta didik dilatih untuk melafalkan huruf-huruf tunggal yang paling mudah dan tidak Arab, kemudian dilatih dengan huruf-huruf dengan tanda panjang dan kemudian dilatih dengan lebih cepat dan seterusnya dilatih dengan melafalkan kata-kata dan kalimat dengan cepat.

ii. Mendorong peserta didik ketika proses pengajaran menyimak dan melafalkan huruf atau kata-kata untuk menirukan intonasi, cara berhenti maupun panjang pendeknya.

2) Mengajarkan kalimat sebelum mengajarkan bahasa

Dalam mengajarkan struktur kalimat, sebaiknya mendahulukan mengajarkan struktur kalimat/nahwu, baru kemudian masalah struktur kata/sharaf. Dalam mengajarkan kalimat/jumlah sebaiknya seorang guru memberikan hafalan teks/bacaan yang mengandung kalimat sederhana dan susunannya benar.

Oleh karena itu, sebaiknya seorang guru bahasa Arab dapat memilih kalimat yang isinya mudah dimengerti oleh peserta didik dan mengandung kalimat inti saja, bukan kalimat yang panjang dan jika kalimatnya panjang hendaknya di penggal - penggal.

\section{Prinsip Koreksitas}


Prinsip ini diterapkan ketika sedang mengajarkan materi fonetik, sintaksis, dan semiotic. Maksud dari prinsip ini adalah seorang guru bahasa Arab hendaknya jangan hanya bisa menyalahkan pada peserta didik, tetapi ia juga harus mampu melakukan pembetulan dan membiasakan pada peserta didik untuk kritis pada hal-hal berikut:

a. Koreksitas dalam pengajaran fonetik.

b. Koreksitas dalam pengajaran sintaksis.

c. Koreksitas dalam pengajaran semiotic.

1) Koreksitas dalam pengajaran fonetik Pengajaran aspek keterampilan ini melalui latihan pendengaran dan ucapan. Jika peserta didik masih sering melafalkan bahasa ibu, maka guru harus menekankan latihan melafalkan dan menyimak bunyi huruf Arab yang sebenarnya secara terus-menerus dan 106ampe pada kesalahan peserta didik.

2) Koreksitas dalam pengajaran sintaksis Perlu diketahui bahwa struktur kalimat dalam bahasa satu dengan yang lainnya pada umumnya terdapat banyak perbedaan. Korektisitas ditekankan pada pengaruh struktur bahasa ibu terhadap bahasa Arab. Misalnya, dalam bahasa Indonesia kalimat akan selalu diawali dengan kata benda (subyek), tetapi dalam bahasa Arab, seperti halnya, Bahasa Arab kalimat bisa diawali dengan kata kerja.

3) Koreksitas dalam pengajaran 106amper106c Dalam bahasa Indonesia pada umumnya setiap kata dasar mempunyai satu makna ketika sudah dimasukan dalam satu kalimat. Tetapi, dalam bahasa Arab (Arab), hamper semua kata mempunyai arti lebih dari satu, yang lebih dikenal dengan istilah musytarak (satu kata banyak arti) dan mutaradif (berbeda kata sama arti). Oleh karena itu, guru bahasa Arab harus menaruh perhatian yang besar terhadap masalah tersebut. Ia harus mampu memberikan solusi yang tepat dalam mengajarkan makna dari sebuah ungkapan karena kejelasan petunjuk.

\section{Prinsip Berjenjang}

Jika dilihat dari sifatnya, ada 3 kategori prinsip berjenjang, yaitu:

a. Pergeseran dari yang konkrit ke yang abstrak, dari yang global ke yang detail, dari yang sudah diketahui ke yang belum diketahui.

b. Ada kesinambungan antara apa yang telah diberikan sebelumnya dengan apa yang akan ia ajarkan selanjutnya.

c. Ada peningkatan bobot pengajaran terdahulu dengan yang selanjutnya, baik jumlah jam maupun materinya. 
1) Jenjang Pengajaran kosa kata. Pengajaran kosa kata hendaknya mempertimbangkan dari aspek penggunaannya bagi peserta didik, yaitu diawali dengan memberikan materi kosa kata yang banyak digunakan dalam keseharian dan berupa kata dasar. Selanjutnya memberikan materi kata sambung. Hal ini dilakukan agar peserta didik dapat menyusun kalimat sempurna sehingga terus bertambah dan berkembang kemampuannya.

2) Jenjang Pengajaran Morfem. Dalam pengajaran morfem juga harus mempertimbangkan kegunaannya dalam percakapan keseharian. Dalam pengajaran morfem misalnya dalam pengajaran bahasa Arab, harus diawali dengan materi tentang kalimat sempurna (Jumlah Mufiidah), namun rincian materi penyajian harus dengan cara mengajarkan tentang isim, fi'il, dan huruf.

3) Jenjang pengajaran makna. Dalam mengajarkan makna kalimat atau kata-kata, seorang guru bahasa Arab hendaknya memulainya dengan memilih katakata/kalimat yang paling banyak digunakan dalam keseharian meraka. Selanjutnya makna kalimat lugas sebelum makna kalimat yang mengandung arti idiomatic.

Dilihat dari teknik materi pengajaran bahasa Arab, tahapan-tahapannya dapat dibedakan sebagai berikut:

a) Pelatihan melalui pendengaran sebelum melalui penglihatan.

b) Pelatihan lisan/pelafalan sebelum membaca.

c) Penugasan kolektif sebelum individu.

\section{B. Langkah-langkah Aplikasi Pengajaran Bahasa Arab}

Langkah-langkah aplikasi dalam pengajaran bahasa Arab, setidak-tidaknya ada delapan yang diperlukan agar teknik penyampaian materi berhasil dan dapat terlaksana, yaitu:

1. Memberikan contoh-contoh sebelum memberikan kaidah gramatika, karena contoh yang baik akan menjelaskan gramatika secara mendalam daripada gramatika saja.

2. Jangan memberikan contoh hanya satu kalimat saja, tetapi harus terdiri dari beberapa contoh dengan perbedaan dan persamaan teks untuk dijadikan analisa perbandingan bagi peserta didik.

3. Mulailah contoh-contoh dengan sesuatu yang ada di dalam ruangan kelas/media yang telah ada dan memungkinkan menggunakannya.

4. Mulailah contoh-contoh tersebut dengan menggunakan kata kerja yang bisa secara langsung dengan menggunakan gerakan anggota tubuh. 
5. Ketika mengajarkan kata sifat hendaknya menyebutkan kata-kata yang paling banyak digunakan dan lengkap dengan pasangannya. Misalnya hitam-putih, bundar-persegi.

6. Ketika mengajarkan sebuah kata dan maknanya, sebaiknya dipilih kata yang paling banyak digunakan dan dimasukkan langsung ke dalam kalimat yang paling sederhana.

7. Hendaknya tidak memberikan contoh-contoh yang membuat peserta didik harus meraba-raba karena tidak sesuai dengan kondisi pikiran mereka.

8. Peserta didik diberikan motivasi yang cukup untuk berekspresi melalui tulisan, lisan bahkan mungkin ekspresi wajah, agar meraka merasa terlibat langsung dengan proses pengajaran yang berlangsung.

\section{Metode Pengajaran Bahasa Arab}

Ibnu khaldun berkata, "Sesungguhnya pengajaran itu merupakan profesi yang membutuhkan pengetahuan, keterampilan, dan kecermatan karena ia sama halnya dengan pelatihan kecakapan yang memerlukan kiat, strategi dan ketelatenan, sehingga menjadi cakap dan professional." Penerapan metode pengajaran tidak akan berjalan dengan efektif dan efisien sebagai media pengantar materi pengajaran bila penerapannya tanpa didasari dengan pengetahuan yang memadai tentang metode itu. Sehingga metode bisa saja akan menjadi penghambat jalannya proses pengajaran, bukan komponen yang menunjang pencapaian tujuan, jika tidak tepat aplikasinya. Oleh karena itu, penting sekali untuk memahami dengan baik dan benar tentang karakteristik suatu metode. Secara sederhana, metode pengajaran bahasa Arab dapat digolongkan menjadi dua macam, yaitu: metode tradisional/klasikal dan metode modern.

Metode pengajaran bahasa Arab tradisional adalah metode pengajaran bahasa yang terfokus pada "bahasa sebagai budaya ilmu" sehingga belajar bahasa Arab berarti belajar secara mendalam tentang seluk-beluk ilmu bahasa Arab itu sendiri, baik aspek gramatika/sintaksis (Qowaid nahwu), morfem/morfologi (Qowaid as-sharf) ataupun sastra $(a d a b)$. Metode yang berkembang dan masyhur digunakan untuk tujuan tersebut adalah Metode morfem/morfologi (qowaid) dan tarjamah. Metode tersebut mampu bertahan beberapa abad, bahkan sampai sekarang lembaga-lembaga pendidikan di Indonesia, khususnya pesantren masih menerapkan metode tersebut. Hal ini didasarkan pada hal-hal sebagai berikut: Pertama, tujuan pengajaran bahasa Arab (Arab) tampaknya pada aspek budaya/ilmu, terutama nahwu dan ilmu sharaf. Kedua kemampuan ilmu nahwu dianggap sebagai syarat mutlak sebagai alat untuk memahami teks/kata bahasa 
Arab klasik yang tidak memakai harakat, dan tanda baca lainnya. Ketiga, bidang tersebut merupakan tradisi turun temurun, sehingga kemampuan di bidang itu memberikan "rasa percaya diri (gengsi) tersendiri di kalangan mereka".

Metode pengajaran bahasa Arab modern adalah metode pengajaran yang berorientasi pada tujuan bahasa sebagai alat. Artinya, bahasa Arab dipandang sebagai alat komunikasi dalam kehidupan modern, sehingga inti belajar bahasa Arab adalah kemampuan untuk menggunakan bahasa tersebut secara aktif dan mampu memahami ucapan/ungkapan dalam bahasa Arab. Metode yang lazim digunakan dalam pengajarannya adalah metode langsung. Munculnya metode ini didasari pada asumsi bahwa bahasa adalah sesuatu yang hidup, oleh karena itu harus dikomunikasikan dan dilatih terus sebagaimana anak kecil belajar bahasa.

\section{Kesimpulan}

1. Ada tiga prinsip dasar dalam pengajaran bahasa Arab, yaitu prinsip prioritas dalam proses penyajian materi ajar, prinsip koreksitas dan umpan balik, prinsip bertahap dalam penyampaian materi kepada peserta didik.

2. Ada beberapa langkah aplikasi yang diperlukan dalam pengajaran bahasa Arab, agar teknik penyampaian materi berhasil dan dapat terlaksana, yaitu: Memberikan contoh sebelum memberikan kaidah gramatika, memberikan contoh kalimat yang biasa dipakai sehari-hari, dan memberikan motivasi yang cukup untuk berekspresi melalui tulisan, lisan bahkan mungkin ekspresi wajah, agar meraka merasa terlibat langsung dengan proses pengajaran yang berlangsung.

3. Ada dua macam metode pengajaran bahasa Arab, yaitu: pertama, metode tradisional, yaitu metode pengajaran bahasa yang terfokus pada "bahasa sebagai budaya ilmu" sehingga belajar bahasa Arab berarti belajar secara mendalam tentang seluk-beluk ilmu bahasa Arab itu sendiri. Dan kedua, metode modern, yaitu metode pengajaran yang berorientasi pada tujuan bahasa sebagai alat komunikasi dalam kehidupan modern.

\section{E. DAFTAR PUSTAKA}

Ahmad, Abdurrahman. Thuruqu Ta'alim al-Lughah al-'Arabiyah. Kairo: Maktabah alNahdah. 1979.

Arifin. Psikologi dan Beberapa Aspek Kehidupan Rohaniyah Manusia. Jakarta: Bulan Bintang. 1977. 
Jurnal Keislaman, Vol. 1, No. 1, Maret

-------. Ilmu Pendidikan Islam, Tinjauan Teoritis dan Praktis Berdasarkan Pendekatan Interdisipliner. Jakarta: Bumi Aksara. 2006.

------. Pendidikan Islam dalam Arus Dinamika. Jakarta: PT. Golden Jaya.1987.

Munir, dkk. Rekonstruksi dan Modernisasi Pendidikan Islam. Yogyakarta: Global Pustaka Utama. 2005.

Qahar, Yahya. Evolusi Pendidikan Agama. Jakarta: Ciawi Jaya. t.t.

Ridla, Muhammad, Jawwad. Tiga Aliran Utama Teori Pendidikan Islam. Yogyakarta: Tiara Wacana. 2002.

Sya'alabi, Ahmad. Tarikh al-Tarbiyah al-Islamiyah. Kaira: tnp.. 1961.

Syalaby, Ahmad. Ta'lim al - Lughah al-'Arabiyah lighairi al - 'Arab. Kairo: Maktabah alNahdhah al-Mishriyah. 1983. 